\title{
A Quantitative and Theoretical Analysis of Ghana's Internal Migration, Economic Growth and poverty Reduction: A Disaggregated Approach, from 1980 to 2012*
}

\author{
Nicholas Awuse (Corresponding author) \\ Bolgatanga Polytechnic \\ P. O. Box 767, Sumbrungu, Bolgatanga, Ghana
}

Tel: 233-243-924-839_E-mail: akaare2002@yahoo.com

Patrick Tandoh-Offin $(\mathrm{PhD})$

Ghana Institute of Management and Public Administration (GIMPA)

P. O. Box AH-50, Achimota-Accra, Ghana

Tel: 233-247-450-433Ｅ-mail: ptandoh@gimpa.edu.gh

Received: October 10, 2013 Accepted: November 1, 2013

doi:10.5296/ber.v4i1.4972 URL: http://dx.doi.org/10.5296/ber.v4i1.4972

\begin{abstract}
The study here was meant to examine the consequence of Ghana's government spending on economic growth, internal migration and poverty reduction in Ghana using a disaggregated approach. It reveals that intensifying government outflow has not yielded any meaningful development in Ghana. Many researches had been conducted on the actual link connecting government expenditure, internal migration, economic growth and poverty reduction. Many of the studies until today have used the aggregate approach which has not yielded the desired results hence there is the need to vary the methodology.

This study made use of the data for the period (1980 - 2012). The findings from the study shows that Government total capital expenses (GTE), total recurrent outflows (GOF), Government cost on education (GCE) and power (POW) on the contrary, impacts negatively on economic growth and was significant. On the other hand, increasing Government spending on transport and communication (GCTC), and health (GDH) leads to an increase in economic
\end{abstract}


growth. From the results above, the authors advised that there should be public private participation in critical sectors of the Ghanaian economy in the areas of power and transport in order to accelerate the rate of development in Ghana. In addition to this recommendation, government should be more transparent and accountable in her spending.

Keywords: Government expenditure, Economic growth, Poverty reduction, Power, Health, Transport, Communication

\section{Introduction}

There is a serious argument among scholars around the world about the relationship between government spending, internal migration and its influence on economic growth. Governments over the world have two basic functions namely, protection (security) and provision of certain essential public goods, Nurudeen and Usman (2010). The protection function consists of the maintenance of rule of law and the enforcement of property rights. These have the potential to reduce the risks of criminality; protect life, property, and defend the nation from foreign attacks. The provisions of public goods such as defense, roads, education, health, and power, to mention a few are very important for any nation's development.

Development specialists are of the view that if government spending on socio-economic and physical infrastructure equally across the country increases, it will encourage economic growth; reduce internal migration, and reduce (add) poverty. A typical example is government expenditure on health and education which are vital, and increases the productivity of labour which raises the growth of national output. In the same vein, expenditure on infrastructure such as roads, communications, power, etc, reduces production costs, increases private sector investment and profitability of firms, thus nurturing economic growth. Low educational attainment is known to be a major factor underlying the exclusion of the poor from the opportunities that come with economic growth (Awuse et al 2014) Ravallion and Datt, 2003).

On the other hand, a number of experts hold a different view and maintain that mounting government spending supports economic growth and ultimately reduces poverty. As an alternative, they call attention to higher government expenditure may contract the overall performance of the economy. For instance, in an effort to increase expenditure, government may raise taxes and/or borrow and crowds out private investment. If there are superior income taxes, it discourages individuals from working for long hours, applying for promotions in the case of regressive tax or even searching for jobs which have the potential to reduce income and aggregate demand. Nevertheless, more profit tax tends to add to production costs and reduce investment expenditure as well as profitability of firms. In Ghana, government disbursement has continued to rise as a result of massive receipts from production and sales of crude oil, and better demand for public goods like roads, communication, and power, Education, Health and Water. Moreover, there is a need to make available both interior and external safety measures for the people and the nation.

Available figures show that government machinery and total spending have continued to go up in the last three decades. In a similar manner, the total government continuous expenditure shows that expenditure on defense, internal security, education, health, agriculture, 
construction, transport and communication increased during the period under review. In addition, the various components of capital expenditure that is, defense, agriculture, transport and communication, education, power, and health also show a rising development between 1980 and 2012.

\section{Problem Statement}

In Ghana, public outflow has a tremendous role to play in reducing regional inequalities, developing social overheads, establishing infrastructure for economic growth in the form of transport and communication conveniences, education and training, growth of capital goods, industries, research and development, were fundamental (Sinha, 2007). A public cost on infrastructure plays a basic role in this economy. According to Dickey and Fuller (1979), the appliance in which government expenses on public infrastructure was anticipated to affect the efficiency of economic growth and minimize poverty depends largely upon the accurate form and size of total public expenditure billed to economic and social development projects in the economy (Guest, 2003). When communal expenditure was incurred, by itself it may be directed to meticulous investments or to bring about re-allocation of the investible resources in the private sector of the economy.

This effect, therefore, was principally in the nature of rearrangement of resources from less to more desirable lines of investment. A vital way in which public expenditure can speed up the pace of economic growth was by tightening down the difference between social and private marginal productivity of confident investment. At this juncture, public expenditure on social and economic infrastructure like education, health, transport, communication, waste disposal, electricity, water and sanitation can make a payment to the show of the economy and hence reducing poverty and internal migration in Ghana. Murphy (2002) notes that internal migration has made major contributions to development, by accelerating economic growth, building up cities and establishing rural-urban linkages and return flows.

\section{Literature Review}

According to Laudau (2003), the share of government consumption to GDP reduces economic growth was consistent with the pro-market view that the growth in government constrains overall economic growth. These findings were significant to varying the sample periods, weighing them by population and a mix of both developed and developing countries (104 countries). Also Ram (1986) makes a rigorous attempt to incorporate a theoretical basis for tracing the impacts of government expenditure to growth through the use of production functions specified for both public and private sectors. The data spanned 115 countries to derive broad generalizations for the market economic investigated. It was discovered that government expenditure has significant positive externality effects on growth particular in the less developed countries (LDC) sample, but total government spending had a negative effect on growth. Lin (1994) uses a sample of 62 countries (1960 - 1985) and found that non- productive spending had no effect in growth in the advance countries but a positive impact in LDCs. In Ghana, government expenditure does not necessarily lead to economic growth; reduce internal migration and promote development. 
Again, many Ghanaians are still experiencing poverty and more than 50 percent of them cannot make ends meet as defined by the United Nation. More so, poor infrastructure generally in Ghana has contributed partly to the falling down of many industries, thus increasing the rate of unemployment. Apart from the above, macroeconomic indicators have not also perform well over the years. It does well only in theory but in practice, it does reflect in the lives of Ghanaian. Therefore, the primary aim of this study is to explore the consequence of government expenditure on economic growth in Ghana. The study concerns itself with some fundamental questions below.

Firstly, does government expenditure have a significant influence on economic growth, internal migration and poverty reduction in Ghana? Secondly what policy measures must be adopted to improve management of government expenditure? Hence, the following hypotheses were formulated to guide the study.

H01: Government total capital expenditure does not have significant influence on economic growth and poverty reduction in Ghana.

H02: Government total capital expenditure has significant influence on economic growth and poverty reduction in Ghana.

H03: Government expenditure on transport and communication does not have significant influence on economic growth and poverty reduction.

H04: Government expenditure on transport and communication has significant influence on economic growth and poverty reduction.

\section{Research Method}

This lesson adopts graphic research design. As a result, the investigative tool used was the single equation, concerning the use of the ordinary least squares (OLS) multiple regression techniques. The government expenditure and the agencies work well to determining economic growth and poverty reduction. The model of this study therefore expresses economic growth (GRY) as a function of various levels and components of government expenditure which include Total Capital Expenditure (GTE), Poverty Reduction (PR) as a function of education and health, Total Recurrent Expenditure (GRE), Expenditures on Defense (ED), Agriculture (AGRE), Transport and Communication (ETC), Education (GEED), Power (POW) and Health $(\mathrm{GEH})$. Thus, the growth model and poverty reduction is specified as follows and all the variables are equally well defined for clarity and analytical purposes:

$\mathrm{GRY}=\beta 0+\beta 1 \mathrm{GTE}+\beta 2 \mathrm{GRE}+\beta 3 \mathrm{ED}+\beta 4 \mathrm{AGRE}+\beta 5 \mathrm{GEED}+\beta 6 \mathrm{GEH}+\beta 7 \mathrm{GETC}+$ $\beta 8 \mathrm{POW}+\mu$

GRY $=-0.745+0.004+0.030-0.767-0.052+0.112+0.121+0.420+0.056$

Economic growth refers to the changes in real GDP. Real GDP in turn is obtained by dividing GDP at current market price by the consumer Price Index (CPI). According to experts, poverty reduction was to have access to essential needs as Education, Health and food, GRE was measured as total recurrent expenditure divided by the CPI. GTE is captured by the total capital 
expenditure divided by CPI. AGRE is captured by government expenditure on agriculture divided by CPI. GEH is measured as government expenditure on health divided by CPI. GEED is captured by government expenditure on education divided by CPI. GETC is measured as government expenditure on transport and communication divided by CPI. POW is captured by government expenditure on power divided by CPI. Thus, we assumed the expenditure items to be actual expenditures. Prior estimation of the growth model above, standard econometric tests like stationary test and co-integration test was conducted in order to avoid the generation of spurious regression results.

\section{Results and Discussion}

In this equation we regressed all the explanatory variables on growth and poverty reduction model. The regression results showed that the explanatory variables jointly account for approximately 55 percentage changes in economic growth. The results showed that only health (GEH) and transport and communication (GETC) were correctly signed in support of the prior expectation, the other explanatory variables were negatively signed against a priori expectation.

The constant term which was the autonomous expenditure, that is government expenditure when all other explanatory variables were fixed was 15.9 percent. The estimation results also show that-total capital expenditure (GET), recurrent expenditure (GRE), expenditures on transport and communication (GETC), education (GEED), and health (GEH), were statistically significant in explaining the changes in economic growth. However, expenditures on defense (ED), power (POW) and agriculture (AGRE) were not significant in explaining economic growth. The Durbin Watson Statistic (2.10) shows the absence of auto correlation. The results also showed that 1 percentage increase in total capital expenditure in the previous two years causes economic growth to decline by 0.004 percentages.

On the other hand, a 1 percentage increase in total recurrent expenditure in the previous one year leads to 0.004 percentage decrease in economic growth. These findings were consistent with the research reported by Laudau (2003), that government expenditure may slowdown economic growth. The misallocation, mismanagement and diversion of public funds may have accounted for the negative impact of total capital and recurrent expenditures by government officials and political appointees. Also, one (1) percent increase on government expenditure on transport and communication in the previous one year results to an increased in economic growth by approximately 0.420 percentage. Thus, higher government expenditure on transport and communication creates an enabling environment for businesses to strive through reduced cost of production. Besides, the estimation shows that a one percentage increase in government expenditure on education in the previous one year causes economic growth to decline by approximately 0.112 percent. This was not surprising because funds meant for the development of the education sector have not been properly utilized and in most cases embezzled, thus precipitating the incessant strike by University Teachers Association of Ghana (UTAG), Polytechnic Teachers Association of Ghana (POTAG), Colleges of Education Teachers Association of Ghana (CETAG), Ghana National Association of Teachers (GNAT). Moreover, the estimated results indicated that a 1 percent increase in expenditure on health in the previous 
one year leads to approximately 0.121 percent increase in economic growth.

The government expenditure on health improves the health status and productivity of people, thereby promoting economic growth. The regression results also illustrated that a 1percentage change in expenditure on power in the previous year results to approximately 0.56 percentage decreases in economic growth. This is not surprising given the fact that in the last twenty decades before 1999, the power sector lacked gross neglect.

Also the billions of dollars spent between 1990s and 2010 by the administration of Presidents Mobutu Sese Seko of then Zaire, and Sani Abacha and Olusegun Obasanjo of Nigeria could not be accounted for. This has resulted in the poor performance of the power industry and the economy at large given the critical role of the power sector in economic development.

\subsection{Data Discussion}

Data availability is a major problem confronting African Countries including Ghana. Two major factors account for the scarcity of data on government expenditure and economic growth. The first is the unwillingness of governments to be open about the true cost of their expenditure on the various sectors of their economies. Some governments generally regard this information as an official state secret and are wary of revealing it. For African states, as for many other developing countries, withholding information on defense for example has three main attractions. One is to avoid criticism from within the country about the extent of the resources committed to defense in relation to other sectors, especially health and education. This is particularly true of states whose resources are meager. A second is the belief that making such information available will be tantamount to opening up the defenses of the state to others, especially neighboring countries - that knowledge of a country's strength will make it vulnerable. The third is that defense, with all the secrecy associated with it, and is a fertile source of corruption for those directly in charge of the portfolio.

It follows that, unless they were compelled to do so or unless there were reasons beyond their control, many African states were not willing to make such information available. The second reason for lack of information in the defense sector was the lack of capacity to report exact expenditure on the military. Over the years this capacity has diminished in many African states because they have lost highly qualified professionals from the government service to the better-paid private sector, including several donor projects.

Other professionals have migrated abroad within the context of the widely reported brain drain, leaving less qualified and usually less competent officers behind. Where highly qualified individuals are still left they are often too few and far between to make any appreciable impact on the budget process. In such states, the political leaders can then exploit this weakness to siphon off resources by diverting significant amounts of state money to defense, knowing full well that they will not be obliged to account for it.

\subsubsection{The Reliability of the Data}

Not only are expenditure data on defense, power, health and education scarce, but the quality of the data that are available is also very low. The problem of the reliability of the available data 
emanates from three factors. The first is the unwillingness of governments to be open about the true cost of their expenditure establishments; in particular, they hide the actual cost of their investment in arms procurement. Such information is regarded as a state secret. The second is the dearth of qualified staff mentioned above, and the third was the reasons for which data are collected and provided.

This study argues that the nature of the reason that motivates a state to provide military expenditure data largely dictates the quality of the data, and hence their reliability. If Ghana Government is compelled by external actors to provide information will be more inclined to give misleading data than one which provides the data as part of routine government work. A large number of African states are now compelled to publish their expenditure, either as a result of demands by donors who provide budget support and want evidence of proper accounting or as a result of strong local demand by critical segments of their societies. Others publish the data purely as part of a routine government accounting procedure, and such data are likely to be of better quality, although reduced state capacity may still take its toll.

Reliability alone does not guarantee the validity of data if valid data are taken to be data that truly capture the whole of a country's spending. A piece of data may be reliable without being valid. The fact that data emanate from government cannot guarantee their validity, since a government could doctor the data to suit its purposes. The problem of constant changes to the heading under which defense, power, health expenditures are budgeted or reported also arises here. A particular item might be listed in one budget under the ministry of defense or otherwise, in another under a ministry for the health, education and in yet another under the ministry for security. Sometimes the change will amount to no more than a change in nomenclature; at other times it could involve a significant impact on the composition of the budget.

This can greatly affect the validity of data, especially in longitudinal studies. If the composition of data changes repeatedly during the period being studied, a study may not be able to measure adequately what it purports to measure.

Data were derived from secondary sources. Pools of data were extracted from publications of the State of the Ghanaian Economy, Ghana Government Budget and Economic Policy Statement for Various Years, Ghana Statistical Service Yearly Report, The world Economic out Look 2006-2009, ISSER and CEPA annual reports. The sample data contain all the six sectors in which government carried out expenditure. The sample data used cover the period 1980 to 2012; and the sectors covered are six in number namely: defense (ED), agriculture (AGRE), transport and communication (GETC), education (GEED), power (POW) and health (GEH). The Regression Analysis was run by Econometric Stata.

\subsubsection{Policy Direction}

Facilitating government expenditure and economic growth in Ghana can minimize the level of internal migration and encourage even development in every aspect of Ghana. This will reduce inequalities in resource allocation and views every sector as important contributing to overall development of Ghana. Ghana government can make it a policy for every sector to submit data to the statistical service as a quarterly or monthly requirements, this will make the data more 
reliable than to wait for donor agencies to demand data from them before they start generating fake data for them. But managing government expenditure to promote economic growth and reduce internal movement of people to seek for greener pastures will minimize in order to maximise the benefits economic growth while reducing costs and risks requires effective partnerships between governments, civil society, private sector organisations and donors.

\section{Conclusion and Recommendations}

The study aims at examining the consequence of government spending on economic growth, discouraging internal migration by ensuring even distribution of resources to all the regions and reduces poverty in Ghana using a disaggregated approach. The experimental results revealed that the negative total current expenditure significantly influences economic growth in Ghana. Although, the negative total capital expenditure significantly influences the economic growth in Ghana, yet the impact of government expenditure on transport and communication on economic growth was positive and significant. On these foundations, the following recommendations are proffered:

(1) Government should not play politics with expenditure on public goods just to win cheap popularity.

(2) The capital expenditure of government which spurs economic growth is presently at about 30 percent of total government expenditure, against recurrent expenditure of 0.004 percent. This trend, if reversed quickly would guarantee economic growth and reduce poverty.

(3) Government should keep an eye on the contract awarding process of capital projects closely, to prevent over estimation of implementation cost. This will bring about significant impact of public investment spending on economic growth.

(4) There should be successful channeling of public funds to productive activities, which will have a significant collision on economic growth.

(5) Government utilization spending should be well harmonized by all arms of government to prevent "Crowding out" effect on government investment.

\section{References}

Central Bank of Ghana (2007). Annual Report and Statement of Account. December 31, pp.23

Central Bank of Ghana (2008). Annual Report and Statement of Account. December 31, pp. 28

Central Bank of Ghana (2009). Annual Report and Statement of Account. December 31, pp. 35

Deloitte (2010). National Health Insurance Authority: Revenue and Expenditure Account for the Year Ended December 31, 2008, Accra.

Dickey, D. A., \& Fuller, W. A. (1979). Distributions of the Estimators for Autoregressive Time Series with a Unit Root, Journal of the American Statistical Association, 74, 427-431.

Ecorys Macro Group (2010). Republic of Ghana Public Expenditure and Financial Accountability 2009. Public Financial Management Performance Assessment Report, Volume 
I: Central Government, Accra.

Global Partnership for Education (2010). Mid-Term Evaluation of the EFA Fast Track Initiative, Washington D.C.

Guest, P. (2003). Bridging the Gap: Internal Migration in Asia, Population Council Thailand, paper prepared for the Conference on African Migration in Comparative Perspective, Johannesburg, South Africa, 4-7 June.

International Monetary Fund (2011). Ghana: Financial System Stability Assessment Update, Country Report 11/31, June, Washington D.C.

Laudau D. (2003). Testing Wagner's Law for Turkey, 1960-2000. Review of Middle East Economics and Finance, 1(12), 129-140.

Lin, W. (1994). A Re-examination of Wager's Law for Ten Countries Based on Co-integration and Error Correction Modeling Technique. Applied Financial Economics, 14, 577-589.

Murphy, R. (2002). How Migrant Labour is Changing Rural China, Cambridge: Cambridge

Nigerian Stock Exchange Fact Book (2001). 2005 and 2010 Editions, Published by Pathways Communications Ltd, Lagos State.

Nurudeen A. \& A. Usman (2010). Government Expenditure and Economic Growth in Nigeria, 1979-2008: A Disaggregated analysis. Business and Economics Journal, 4, 1-11.

Ram, A. (1986). Causality between Income and Public Expenditure: A Broad International Perspective. Public Finance, 41(1), 393-414.

Ravallion, M., \& Datt, G. (2003). Is India's Economic Growth Leaving the Poor Behind? World Bank Policy Research Working Paper No 2846, Washington, DC: World Bank.

Sinha, D. (2007). Does the Wagner's Law Hold for Thailand? A Time Series Study, Available online at http://mpra.ub.uni-muenchen.de/2560/

World Bank (2010b). Republic of Ghana: Improving the Targeting of Social Programs, Washington D.C.

World Bank (2011a). Republic of Ghana: Tackling Poverty in Northern Ghana, Washington D.C.

World Bank (2011b). Republic of Ghana: Improving Equity, Efficiency and Accountability of Education Service Delivery, Washington D.C.

\section{Copyright Disclaimer}

Copyright reserved by the author(s).

This article is an open-access article distributed under the terms and conditions of the Creative Commons Attribution license (http://creativecommons.org/licenses/by/3.0/). 